\section{BIOMEDICAL TWX, NEW YORK}

Ten members of the Medical Library Center of New York are now linked, with MLC and with each other, in a TWX communications network which began transmission of messages on May 1. With the exception of the teletypewriter in the New York Academy of Medicine, which was supplied by the state of New York, the equipment installation and monthly rental fees are paid by the Medical Library Center; the individual libraries pay their own transmission charges. Thus far, the TWX network includes only the sponsoring members of the Medical Library Center. In addition to the New York Academy of Medicine these are the medical libraries of Columbia University, and Cornell University, Albert Einstein College of Medicine, New York Medical College, New Jersey College of Medicine and Dentistry, Rockefeller University, Memorial Sloan-Kettering Cancer Center, and Mount Sinai Hospital Jacobi library.

The New York Academy of Medicine has been designated the resource library for materials on medicine and psychology under the State of New York's Reference and Research Resources Program. The state has entered into contract with eleven major research libraries - eight subject and three area referral centers. The resource libraries are linked by teletype to the state library, which serves as a switching center for requests for materials not supplied locally through public library systems. The contract permits reimbursement by the State of New York for each request filled by the resource library and provides, as well, for partial payment for the processing of unfilled requests. The resource payment for the processing of unfilled requests. The resource library has the option of honoring requests by lending the physical volume or providing photocopy.

The TWX installations facilitate interlibrary loan transactions not only in New York City and New York State, but provide another means of communication between medical libraries in New York City and those in other parts of the country. The call numbers of the MLC network were assigned too late to be included in the 1967 TWX Directory, but a list of them may be obtained from Mrs. Jacqueline W. Felter, Acting Director, Medical Library Center of New York, 17 East 102nd Street, New York, N.Y. 10029.

$\begin{array}{ll}\text { ACRL Membership, June 30, } 1967 & 11,614 \\ \text { ACRL Membership, July 31, } 1966 & 10,528\end{array}$

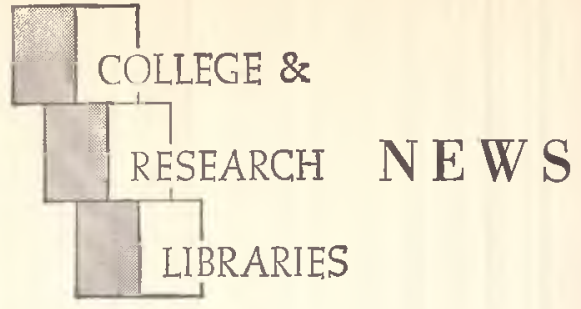

ACRL News Issue of College \& Research Libraries

Editor, David Kaser, Joint University Libraries, Nashville, Tenn. 37203.

Publications Officer, Mary Falvey, 50 E. Huron St., Chicago 60611.

ACRL Executive Secretary, George M. Bailey.

ACRL Officers, 1967/68: President, James Humphry III; College Libraries Section Chairman, Audrey North; Junior College Libraries Section, Mrs. Alice B. Griffith; Rare Books Section, Lawrence S. Thompson; Subject Specialists Section, Richard L. Snyder; Agriculture and Biological Sciences Subsection, Mrs. Pauline W. Jennings; Art Subsection, James K. Dickson; Law and Political Science Subsection, (Name to come); Slavic and East European Subsection, Jerzy (George) J. Maciuszko; University Libraries Section, Stuart Forth

Editorial Board: John M. Dawson, University of Delaware; Gustave A. Harrer, Boston University; SaMUEL ROTHSTEIN, University of British Columbia James E. Skipper, Princeton University; Norman E. Tanrs, Kansas State College of Pittsburg; Mauruce F. Tauber, Columbia University; Eileen Thornton, Oberlin College.

News from the Field, Personnel profiles and notes, classified advertising, official matter of ACRL, and other material of a timely nature is published in the News issues of College \& Research Libraries.

Inclusion of an article or advertisement in CRL does not constitute official endorsement by ACRL or ALA.

Production and Advertising and Circulation office: 50 E. Huron St., Chicago, Ill. 60611. Change of address and orders for subscriptions should be addressed to College of Research Libraries, for receipt at the above address, at least two months before the publication date of the effective issue.

Subscription to $C R L$ is included in membership dues to $A C R L$ of $\$ 6$ or more; other subscriptions to $C R L$ are $\$ 10$ per year. Neither subscriptions nor memberships include miscellaneous unscheduled supplements, which are available by purchase only. Retroactive subscriptions are not accepted. Single journal copies are available at $\$ 1.50$ each and News issues at $\$ 1.00$ each from ALA Publishing Department.

Indexed in Library Literature. Abstracted in Library Science Abstracts. Book reviews indexed in Book Review Index.

College \& Research Libraries, is the official journal of the Association of College and Research Libraries, division of the American Library Association; and is published seventeen times per year-bi-monthly as a technical journal with II montbly News issues, combining July-August-at 1201-05 Bluff St., Fulton, Mo. 65251 .

Second-class postage paid at Fulton, Mo. and at additional mailing offices. 